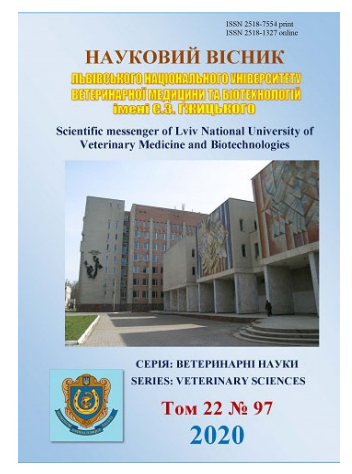

\author{
Науковий вісник Дьвівського національного університету \\ ветеринарної медицини та біотехнологій імені С.3. Гжицького. \\ Серія: Ветеринарні науки \\ Scientific Messenger of Lviv National University \\ of Veterinary Medicine and Biotechnologies. \\ Series: Veterinary sciences
}

UDC 636.22/.28.087

\title{
Effect of additives and various microorganisms on fermentation in the rumen
}

\author{
O. I. Sklyar, I. V. Gerun
}

Sumy National Agrarian University, Sumy, Ukraine

Article info

Received 24.02.2020 Received in revised form 24.03.2020

Accepted 25.03.2020

Sumy National Agrarian University, Gerasim Kondratieva Str., 160, Sumy, 40021, Ukraine. Tel.: +38-095-258-95-61 E-mail:rittyru@gmail.com
Sklyar, O. I., \& Gerun, I. V. (2020). Effect of additives and various microorganisms on fermentation in the rumen. Scientific Messenger of Lviv National University of Veterinary Medicine and Biotechnologies. Series: Veterinary sciences, 22(97), 175-180. doi: $10.32718 /$ nvlvet 9728

The article provides information on the use of drugs to improve scarring. Some changes in the composition of the diet may improve the profile of fermentation of microorganisms. Diarrhea is the main cause of morbidity and mortality of calves at an early age, so its prevention is important for stimulating the development of calves. However, due to the growing risk of antibiotic resistance being released into the environment and entering animal products, probiotic supplements have been developed as an alternative to improve animal health and productivity. Although the administration of probiotics to animals has been linked to the efficacy of certain groups (pathogens) in the gut microbiota, it is currently unclear how they interact with the entire gut society.Probiotics and prebiotics have the ability to regulate the balance and activity of the microbiota of the gastrointestinal tract, and are therefore considered beneficial to animals and used as a functional feed. Feeding restrictions have shown that they significantly affect the structure and activity of the gut microbial cultures of ruminants. Probiotics are micro-organisms that are not of scar origin but can be adapted to scar conditions and improve the fermentation process. Probiotics are defined as living microorganisms or components of microbial cells that favorably affect the host organism as they regulate the gut microbiota in order to improve animal health. inconsistent, perhaps because the dynamics of gastrointestinal development have not been taken into account. Probiotics may be used to reduce the risk or severity of pathological conditions in stressful conditions caused by impaired bowel function. Probiotics used in feed for ruminants mainly include fungi and bacteria that have replaced traditional antibiotics. In healthy calves in which the microorganism culture is relatively stable, the minimal benefits of probiotics may be noticeable. Probiotic yeast organisms have been introduced to increase the effectiveness of the scar to regulate the microflora. The focus is on the benefits of probiotics and prebiotics for the gastrointestinal ecosystem microbiome in ruminants, which are closely related to animal feeding and health.

Key words: rumen, gastrointestinal tract, yeast, probiotics, prebiotics.

\section{Вплив добавок та різних мікроорганізмів на процеси бродіння в рубці}

\author{
О. I. Скляр, І. В. Герун
}

Сумський національний аграрний університет, м. Суми, Украӥна

В статті наведено дані щзодо використання препаратів для поліпшення рубцевого травлення. Деякі зміни в складі раціону можуть поліпшити профіль ферментації мікроорганізмів. Діарея є основною причиною захворюваності та смертності телят в ранньому віці, тому ї̈ профілактика важлива для стимулювання розвитку телят. Проте у зв 'язку зі зростаючою небезпекою шчодо появи стійкості до антибіотиків, щзо викидаються в навколишнє середовище і потрапляють в продукти тваринного походження, були розроблені пробіотичні добавки як альтернатива для поліпшення здоров'я $і$ продуктивності тварин. Хоча призначення пробіотиків тваринам було пов'язано з ефективністю щзодо певних груп (патогенів) в мікробіоти кишечнику, в даний час залишається неясним, як вони взаємодіють з усім вмістом кишечнику. Пробіотики та пребіотики мають здатність регулювати баланс і активність мікробіоти шлунково-кишкового тракту, через щзо вважаються корисними для тварин і використовуються як функціональний корм. Обмеження в годівлі показали, щьо вони помітно впливають на структуру і діяльність кишкових мікробних 
культур жуйних тварин. Пробіотики - це мікроорганізми, які не є рубцевого походження, але можуть бути адаптовані до рубиевих умов $і$ покращувати процес бродіння. Пробіотики визначаються як живі мікроорганізми або компоненти мікробних клітин, які сприятливо впливають на організм господаря, оскільки вони регулюють мікрофлору кишечнику з метою поліпшення здоров'я тварин. Попередні дослідження показали потенційні можливості пробіотиків та пребіотиків в годівлі тварин, але їхня ефективність часто варіюється $і$ є непослідовною, можливо, тому, що динаміка розвитку шлунково-кишкової культури не була взята до уваги. Для зниження ризику або тяжкості наслідків патологій у стресових умовах, щуо викликані порушенням нормальної роботи кишечнику, можуть використовуватись пробіотики. Пробіотики, шуо використовуються в кормах для жуйних тварин, в основному включають в себе грибки $і$ бактерії, які замінили традиційні антибіотики. У здорових телят, в яких культура мікроорганізмів відносно стабільна, можуть бути помітні мінімальні переваги пробіотиків. Пробіотичні дріжджові організми були введені з метою підвищення ефективності роботи рубия для регулювання мікрофлори. Основна увага приділена перевагам пробіотиків та пребіотиків для мікробіому шлунково-кишкової екосистеми у жуйних тварин, які тісно пов'язані з годівлею $i$ здоров'ям тварини.

Ключові слова: рубець, шлунково-кишковий тракт, дріжджі, пробіотики, пребіотики.

\section{Вступ}

Дослідниками зазначено, що екологічні та стохастичні (ймовірні) фактори, такі як дієтичний харчовий раціон, практика годівлі, чинять сильний вплив на склад і функції мікробіоти у жуйних тварин (Tilley \& Terry, 1963; Taylor et al., 2002; Seymour et al., 2005; Kozlovska et al., 2011; Kolesova et al., 2017). Вивчалася шлунково-кишкова мікробна культура в кишечнику людини, котра складається щонайменше 3 тисячі різних видів мікроорганізмів, які впливають на енергоефективність господаря, включаючи перетравлення і зберігання енергії. У жуйних же тварин велика кількість енергії, одержуваної 3 дієтичних полісахаридів, які не можуть бути перетравлені господарем, пов'язана 3 функцією мікробних культур в рубці. Велика частина шлунковокишкової бактеріальної культури ссавців пов'язана 3 двома типами Bacteroidetes та Firmicutes. 3 іншого боку, інші типи мають ніші в будь-якому співтоваристві, залежно від виду тварини. Таким чином, мікробіум шлунково-кишкового тракту $\epsilon$ унікальним серед видів, які вимагають наявності різних систем для ефективного перетворення в енергію. Основні бактерії у великої рогатої худоби складають до 90 \% від загальної кількості культур (Stehnii \& Huzhvynska, 2005). Однак певна частина культур бактерій кишечнику ще не ідентифікована через неповне розуміння структури мікроорганізмів в шлунково-кишковій екосистемі, тому що багато видів, досліджених зі зразків фекалій, отримані з невідомих (тобто раніше не ідентифікованих в кишковій мікрофлорі видів) (Tudisco et al., 2010). Тимчасом як екосистеми шлунково-кишкового тракту у людини відомі, більша частина бактерій у ВРХ залежить від годівлі (Tudisco et al., 2009). Потрібні подальші дослідження, щоб виявити більшу частину невідомих мікроорганізмів, присутніх в мікробіоті шлунковокишкового тракту.

Пробіотики - це мікроорганізми, які не є рубцевого походження, але можуть бути адаптовані до рубцевих умов і поліпшувати процес бродіння. Пробіотики визначаються як живі мікроорганізми або компоненти мікробних клітин, які сприятливо впливають на організм господаря, оскільки вони регулюють мікрофлору кишечнику 3 метою поліпшення здоров'я тварин (Paraniak et al., 2018;
Fedak et al., 2018). Пробіотики, що використовуються в кормах для жуйних тварин, в основному включають в себе грибки і бактерії, які замінили традиційні антибіотики. Для цієї мети в кормах для тварин використовуються специфічні види бактерій (Huzhvynska, 2014). У системах виробництва м'ясної худоби антибіотики використовуються для зниження частоти метаболічних порушень, підвищення ефективності та зниження рівня рубцевого ацидозу, проте використання деяких неприродних антибіотиків обмежено (Van Soest et al., 1991). Пробіотики мають здатність стимулювати розвиток здорової мікробіоти, підвищуючи перетравну здатність, знижуючи $\mathrm{pH}$ i покращуючи імунітет слизової оболонки, запобігаючи заселенню патогенних організмів у кишечнику. Важливо, щоб введені мікроби не стали антагоністичним середовищем до вже адаптованого середовища шлунково-кишкового тракту. Крім того, існує ряд вимог до алохтонних видів пробіотиків для адаптації до кишкового середовища слизової оболонки кишечнику i глікопротеїну у тварин. Ситуація в рубці дещо схожа, введені мікроби повинні знайти придатну для існування нішу, таку як рубцевий епітелій, рубцева рідина або волокнистий корм, i впливати на здоров'я господаря та видалення токсичних молекул і перетравлювання полімерів (Weinberg et al., 1995; Weissbach, 1996; Warren et al., 2002).

Пребіотики - це неперетравлювані кормові інгредієнти, при вживанні яких в достатній кількості вибірково стимулюється ріст і активність одного або обмеженої кількості мікробів в кишечнику. Вплив пробіотиків i внутрішніх корисних бактерій шлунково-кишкового тракту можуть бути посилені за рахунок використання пребіотиків. Для отримання користі для здоров'я тварини найчастіше використовуваними пребіотиками $\epsilon$ вуглеводні субстрати, такі як олігосахариди або кормова клітковина 3 низькою засвоюваністю.

Дослідження пробіотиків і пребіотиків розвивалися спільно в галузях продовольства і кормів та разом з медициною і фармацевтикою (Zahiroddini et al., 2004; 2006). Існує також ряд прикладних досліджень в галузі скотарства; однак лише деякі 3 них обговорювалися у зв'язку з динамікою набутих мікроорганізмів.

Мета досліджень - застосування пробіотичних 
препаратів для формування мікробіоценозу шлунковокишкового тракту тварин та їх корекція.

\section{Матеріал і методи досліджень}

Для проведення досліду були сформовані за методом пар-аналогів 2 групи телят чорно-рябої породи 5-тижневого віку з середньою живою масою $49,53 \pm 1,44$ кг. Тварини 1 групи (5 голів) були контрольними, телята 2 групи (10 голів) - дослідними i отримували 3 молоком один раз на добу препарат молочнокислих бактерій по 1 г/гол. 3 5-тижневого віку протягом 21 діб. Телята отримували молозиво, а потім молоко та інші корми відповідно до загальноприйнятих норм. Перед початком досліду, після закінчення випоювання препарату i через 1 місяць після закінчення випоювання препарату в 5 тварин $з$ кожної групи вранці до згодовування брали проби крові $з$ яремної вени для аналізів. Отримані цифрові дані оброблені методом варіаційної статистики. Для виявлення статистичних відмінностей використаний критерій Стьюдента.

\section{Результати та їх обговорення}

У молодих жуйних тварин пробіотики, такі як LAB або Бацилли, зазвичай націлені на нижню частину кишечнику і являють собою цікавий засіб стабілізації мікробіоти кишечнику і зниження ризику колонізації патогенних мікроорганізмів. LAB - добре відома пробіотична добавка для молодих телят, що вважається прийнятною для регулярного застосування. Попередні результати підтверджують сприятливий вплив на баланс мікробіоти шлунковокишкового тракту, а також на годівлю і здоров'я тварин (табл. 1).

\section{Таблиця 1}

Кількість мікроорганізмів у шлунково-кишковому тракті телят

\begin{tabular}{|c|c|c|c|c|}
\hline \multirow{2}{*}{$\begin{array}{c}\text { Ділянки шлунково- } \\
\text { кишкового тракту } \\
\text { Area gastrointestinal tract } \\
\end{array}$} & \multicolumn{4}{|c|}{ Групи мікроорганізмів } \\
\hline & Лактобактерії & $\begin{array}{l}\text { Біфідобактерії } \\
\text { Bifidobacteria }\end{array}$ & $\begin{array}{l}\text { Анаеробні коки } \\
\text { Anaerobic соссі }\end{array}$ & $\begin{array}{l}\text { Гриби } \\
\text { Fungus }\end{array}$ \\
\hline $\begin{array}{c}\text { Сичуг } \\
\text { Abomasum }\end{array}$ & 1,8 & 0,3 & 0,3 & 0,6 \\
\hline $\begin{array}{c}\text { Дванадцятипала кишка } \\
\text { Duodenum }\end{array}$ & 0,4 & 0,8 & 1,4 & 27800 \\
\hline $\begin{array}{c}\text { Порожня кишка } \\
\text { Jejunum }\end{array}$ & 0,3 & 0,6 & 0,2 & 600000 \\
\hline $\begin{array}{l}\text { Клубова кишка } \\
\text { Ileum }\end{array}$ & 1,4 & 0,4 & 1,3 & 34 \\
\hline $\begin{array}{l}\text { Сліпа кишка } \\
\text { Cаесum }\end{array}$ & 0,6 & 1,2 & 0,5 & 26 \\
\hline $\begin{array}{l}\text { Ободова кишка } \\
\text { Colon }\end{array}$ & 0,8 & 0,5 & 0,6 & 51 \\
\hline $\begin{array}{l}\text { Пряма кишка } \\
\text { Rectum }\end{array}$ & 0,5 & 1,1 & 0,5 & 26 \\
\hline
\end{tabular}

Примітка: * - ${ }^{*} \leq 0,05$ порівняно зі здоровими тваринами

Оптимізація кишкової флори вважається ефективною для здорового вирощування телят, бо вона збільшує кількість корисних мікроорганізмів. Забезпечення мікроорганізмами корів 3 народження 3 профілактичною метою дозволяє об'єднати і встановити ці види пробіотиків разом з мікробіотою телят. Крім того, раннє заселення LAB кишкової екосистемі може знизити приєднання патогенів до слизової оболонки кишечнику. Було показано, що стабільне мікробне навантаження видів Лактобацили Lactobacillus поліпшує набір ваги та імунокомпетентність у молодих телят, однак попередні дані щодо використання пробіотиків при годівлі телят зазвичай були неоднозначними. Ефективність видів пробіотиків може варіюватися залежно від того, чи вирощуються телята в здорових умовах, оскільки в попередніх дослідженнях ефект пробіотиків часто був вищим, коли контрольні телята були слабкими, що визначалося за кількістю фекалій або ректальної температури. У стресових умовах для зниження ризику або тяжкості ушкоджень, викликаних порушенням нормальної роботи кишечнику, можуть використовуватися мікроорганізми, одержувані прямим згодовуванням. Потрібне краще розуміння того, як обрані види лактобактерій i біфідобактерій долають вплив патогенних мікроорганізмів: шляхом антагонізаціі патогенності й модулювання імунних реакцій на інфекції. Деякі види бактерій родів Lactobacillus i Bifidobacterium показали добрі результати як пробіотики у жуйних тварин, збільшуючи рівень приросту ваги та продуктивності. Крім того, було відмічено, що ці молочнокислі бактерії здатні знизити ризик ентеральних захворювань, що викликаються кишковою паличкою і сальмонелою.

Грибки Aspergillus oryzae, Saccharomyces cerevisiae та Candida levica використовувалися як пробіотики, а також харчові добавки для поліпшення процесу 
бродіння рубця. A. oryzae поліпшує використання молочної кислоти декількома бактеріями, такими як Megasphaera elsdenii та Selomonas ruminantium, що дозволяє уникнути зниження рН відразу після годівлі. $S$. cerevisiae сприяє метаболізму мікроорганізмів рубця, оскільки він підвищує рН рубця або зменшує час, протягом якого рН становить менше 5,6, збільшує співвідношення бутирату i пропіонату, а також підвищує засвоюваність сухої речовини i нейтрального волокна. Крім того, дріжджові культури стимулюють використання $\mathrm{H}^{+}$ацетогенними бактеріями, тим самим знижуючи виробництво метану. Присутність Saccharomyces cerevisiae сприяє створенню фібринолітичних бактерій у вигляді $F$. succinogenes та $R$. albus, а також зменшує популяцію мікроорганізмів, які виробляють молочну кислоту, та мікроорганізмів, що використовують $\mathrm{H}^{+}$ для виробництва $\mathrm{CH}_{4}$. Крім того, $\mathrm{S}$. cerevisiae стимулює розмноження грибків $N$. frontalis та виробництво молочної кислоти 3 використанням M. elsdenii та S. ruminantium, запобігаючи зниженню $\mathrm{pH}$ рубця, покращуючи ферментацію волокон і збільшуючи виробництво пропіоната. Всі ці результати свідчать про те, що ці добавки вигідні 3 точки зору збільшення ваги та виробництва молока. У жуйних тварин пробіотики показали позитивний ефект у відлучених телят та збільшення продуктивності молочних корів, засвоєння поживних речовин, ефективність, збільшення ваги м'ясної худоби, а також більшу стійкість до шлунковокишкових захворювань.

Цукор запобігає адгезії ентеробактерій (кишкова паличка Escherichia coli i сальмонела) до епітелію кишечнику. Галактозо-лактоза (ГЛ) - це трисахарид (галактоза плюс лактоза), який утворюється при ферментативній обробці сироватки бетагалактозидази. Додавання ГЛ в замінник молока (3М) раніше мало позитивний вплив на розвиток і здоров'я молочних телят. Додавання МОС, ФОС і ГЛ може поліпшити показники розвитку телят як на стадії до, так і після відлучення; однак зміни в активності мікробної ферментації цими цукрами ще не детально вивчені. Більшість пребіотиків можуть не мати очевидного позитивного ефекту порівняно 3 пробіотиками. Згодовування целюлозоолігосахариду (ЦС), що $є$ комерційно доступним олігосахаридом, підвищує продуктивність i впливає на кишкову екологію у телят, яких годували ЗМ або цільним молоком. Істотних відмінностей у складі фекальних спільнот бактерій або профілях органічних кислот в групі 3М не спостерігалося. Однак ця добавка, мабуть, ефективно модулює кишкове бактеріальне співтовариство кишечнику телят при прийомі 3 цільним молоком, бо частка групи Коккоїдів Клостридії була вище в пребіотичній групі в дослідженні 3 цільним молоком. Виходячи 3 цих результатів, тип рідкого корму (ЗМ або незбиране молоко) для телят до відлучення може відповідати за різні реакції на годівлю ЦС. Загалом додавання ЦС не виявила ніякого впливу на підтримання рівня видів Лактобацили (Lactobacillus) i Біфідобактерій (Bifidobacterium) в товстій кишці телят до відлучення. Вважається, що ЦС використовується специфічними мікробами, які мешкають в кишечнику теляти, і це призводить до збільшення числа бактерій, що продукують масляну кислоту і належать до Коккоїдів Клостридії. Концентрації бутирату калу в той час також були вищі. Поряд 3 його значенням як джерела енергії, бутират також бере участь в рості та диференціюванні клітин кишечнику в товстій кишці, чим поліпшує його епітеліальну структуру, підвищує ефективність травлення i всмоктування, що може сприяти вищій здатності до засвоєння корму. ЦС, що задається з рідким кормом (молоком або відновлене 3М), може досягти нижньої частини травного тракту в рефлексі шлунково-кишкового тракту i надавати пребіотичний ефект, використовуючи механізм, аналогічний механізму моногастальних тварин.

Встановлено, що впродовж застосування пробіотичного препарату у тварин дослідної групи в порівнянні з контролем збільшується вміст загального білка (табл. 2).

\section{Таблиця 2}

Вплив пробіотика на біохімічні показники крові телят

\begin{tabular}{|c|c|c|c|}
\hline Показники & Групи тварин & До застосування & Після застосування \\
\hline \multirow{2}{*}{ Загальний протеїн, г/л } & $\mathrm{K}$ & $72,6 \pm 1,60$ & $77,3 \pm 2,30$ \\
\hline & Д & $80,3 \pm 3,20$ & $78,2 \pm 2,60$ \\
\hline \multirow{2}{*}{ Альбуміни, \% } & K & $42,4 \pm 2,6$ & $44,3 \pm 1,6$ \\
\hline & Д & $44,0 \pm 2,0$ & $42,0 \pm 1,2$ \\
\hline \multirow{2}{*}{$\alpha$-глобуліни, \% } & K & $6,2 \pm 0,1$ & $8,3 \pm 1,4$ \\
\hline & Д & $9,0 \pm 1,2$ & $7,0 \pm 1,0$ \\
\hline \multirow{2}{*}{$\beta$-глобуліни, \% } & K & $12,0 \pm 1,0$ & $12,4 \pm 2,0$ \\
\hline & Д & $14,0 \pm 1,0$ & $13,5 \pm 2,1$ \\
\hline \multirow{2}{*}{ ү-глобуліни, \% } & K & $11,3 \pm 0,5$ & $13,2 \pm 1,1$ \\
\hline & Д & $11,9 \pm 1,3$ & $14,5 \pm 1,2$ \\
\hline \multirow{2}{*}{ БАСК, \% } & K & $29,54 \pm 2,60$ & $38,59 \pm 1,70$ \\
\hline & Д & $25,30 \pm 2,30$ & $44,20 \pm 2,40$ \\
\hline \multirow{2}{*}{ ЛАСК, \% } & K & $8,44 \pm 0,70$ & $9,36 \pm 0,80$ \\
\hline & Д & $9,36 \pm 0,90$ & $15,4 \pm 0,60$ \\
\hline
\end{tabular}

Примітка: *-P $<0,05, * * *-\mathrm{P}<0,001$ порівняно з контролем 
Аналіз проведених досліджень свідчить про позитивний вплив пробіотика на показники імуноглобулінів, які підвищуються в середньому на 5 \%. У процесі використання тваринам препарату спостерігається зростання БАСК - до 44,20 $\pm 2,40 \%$, ЛАСК - до $15,4 \pm 0,60(\mathrm{P}<0,05)$.

Дослідження показали, що згодовування телятам добавок після відлучення збільшило добовий приріст і ефективність годівлі, але не в період до відлучення. Це, можливо, було викликано, головним чином, посиленням румінальної ферментації, оскільки підвищилися рівні пропіоната i загальний рівень жирних кислот 3 коротким ланцюгом (ЖКЛ), що дозволяє припустити, що ЦС впливав на характер ферментації, забезпечення джерел вуглецю та енергії. Після відлучення тверді корми потрапляють безпосередньо в рубець, а потім піддаються мікробіологічної обробці. За винятком дуже молодих жуйних тварин, пребіотики, що вводяться перорально, засвоюються мікробами румінального походження i не доходять до нижньої частини кишечнику, якщо вони не захищені від перетравлення руміналом. Пробіотики для жуйних тварин в основному застосовують для покращення перетравлювання клітковини мікроорганізмів рубця. Встановлено, що вони позитивно впливають на різні процеси травлення, особливо на целюлолітичний аналіз і синтез мікробних білків. Основною формою пробіотика, який зазвичай використовується у молочних корів, є різні види дріжджів (в основному пекарські дріжджі). Що стосується бактеріальних пробіотиків, то бактерії, що продукують лактат (ентерококи, лактобактерії), які підтримують молочну кислоту на більш сталому рівні, ніж стрептококи bovis, можуть бути використані як засіб профілактики ацидозів у тварин, яких годували концентрованими кормами. Megasphaella elsdenii або Пропіонокислі бактерії також вводилися як мікроорганізми прямого згодовування, щоб уникнути накопичення румінального лактату.

Рубцева ферментація є результатом метаболізму бактерій, грибків та простих одноклітинних організмів, присутніх в цьому середовищі. Їхні метаболічні шляхи взаємопов'язані таким чином, що кінцевий продукт або проміжні метаболіти будь-якого типу мікроорганізмів $\epsilon$ субстратом іншого, що необхідних для годівлі жуйних тварин, досягаючи кінцевих продуктів рубцевого бродіння.

\section{Висновки}

Здоров’я шлунково-кишкового тракту можна визначити як здатність підтримувати баланс екосистеми ШК. Бажані зміни в мікробіоті можуть бути пояснені впливом пробіотиків і пребіотиків, а не вегетативними змінами. Дослідження показали, що пробіотики покращили баланс мікробіоти великої рогатої худоби, динаміку i функції рубцевої спільноти. Поліпшення рубцевого бродіння призводить до збільшення виробництва продукції тваринництва. Встановлено позитивний вплив на целюлолітичний аналіз і синтез мікробних білків. Встановлено, що додавання пробіотика жуйним тваринам сприяло поліпшенню засвоєння поживних речовин, збільшенню ваги, а також більшій стійкості до шлунково-кишкових захворювань. Призначення прийому пребіотиків відлученим i не відлученим телятам є вигідним, оскільки формування у телят бажаної кишкової (рубець або нижня частина кишечнику) мікробіоти може сприяти подальшому поліпшенню показників розвитку в старшому віці.

Перспективи подальших досліджень. Подальші дослідження структури i діяльності мікробіоти кишечника, функціональних взаємодій між мікробами кишечнику i відносин між мікробами і клітинамигосподарями необхідні для визначення фундаментальних аспектів майбутніх пробіотичних та пребіотічних досліджень.

\section{References}

Fedak, N., Chumachenko, S., Darmohray, L. M., Gutyj, B. V., \& Perederiy, M. H. (2018). The effectiveness of the use of probiotics for wet maize grain preserving. Scientific Messenger of Lviv National University of Veterinary Medicine and Biotechnologies, 20(89), 8588. doi: 10.32718/nvlvet8916.

Huzhvynska, S. O. (2014). Vidbir molochnokyslykh bakterii dlia vyhotovlennia probiotychnykh preparativ. Veterynarna medytsyna, 99, 196-201 (in Ukrainian).

Kolesova, E. A., Teraevich, A. S., \& Lajons, D. A. (2017). Probiotiki dlja krupnogo rogatogo skota. Materialy Mezhdunarodnoj (zaochnoj) nauchnoprakticheskoj konferencii, 106-111 (in Russian).

Kozlovska, H. V., Danylenko, S. H., \& Skybitskyi, V. H. (2011). Antahonistychni ta adhezyvni vlastyvosti bifidobakterii, vydilenykh vid teliat. Naukovyi visnyk Lvivskoho natsionalnoho universytetu veterynarnoi medytsyny im. S.Z. Hzhytskoho, 13(4), 177-181 (in Ukrainian).

Paraniak, R., Kalyn, B., \& Nahirniak, T. (2018). Value and feasibility of probiotic use. Scientific Messenger of LNU of Veterinary Medicine and Biotechnologies. Series: Veterinary Sciences, 20(87), 116-121. doi: $10.15421 /$ nvlvet8723.

Seymour, W. M., Campbell, D. R., \& Johnson, Z. B. (2005). Relationship between rumen volatile fatty acid concensentrations and milk production dairy cows: a literature study. Animal Feed Science and Technology, 119, 155-169.

Stehnii, B. T., \& Huzhvynska, S. O. (2005). Probiotyky u tvarynnytstvi. Visnyk ahrarnoi nauky, 2, 26-29 (in Ukrainian).

Taylor, C. C., Ranjit, N. J., Mills, J. A., Neylon, J. M., \& Kung, L. (2002). The effect of treating whole-plant barley with Lactobacillus buchneri 40788 on silage fermentation, aerobic stability, and nutritive value for dairy cows. J Dairy Sci., 85(7), 1793-1800. doi: $10.3168 /$ jds.S0022-0302(02)74253-7. 
Tilley, J. M. A., \& Terry, R. A. (1963). A two-stage technique for the in vitro digestion of forage crops. J $\mathrm{Br}$ Grassland Soc., 18(2), 104-111. doi: 10.1111/j.1365-2494.1963.tb00335.x.

Tudisco, R., Calabrò, S., Grossi, M., Piccolo, G., Guglielmelli, A., Cutrignelli, M. I., Caiazzo, C., \& Infascelli, F. (2010). Influence of replacing corn silage with barley silage in the diets of buffalo cows on milk yield and quality. Vet. Res. Commun., 34(1), S193S196. doi: 10.1007/s11259-010-9406-1.

Tudisco, R., Calabrò, S., Terzi, V., Piccolo, V., Guglielmelli, A., \& Infascelli, F. (2009). In vitro fermentation of ten cultivars of barley silage. Italian J. Anim. Sci., 8(2), 343345. doi: 10.4081/ijas.2009.s2.343.

Van Soest, P. J., Robertson, J. B., \& Lewis, B. A. (1991). Methods for dietary fiber, neutral detergent fiber and non-starch polysaccharides in relation to animal nutrition. J Dairy Sci., 74(10), 3583-3597. doi: 10.3168/jds.S0022-0302(91)78551-2.

Warren, H. E., Tweed, J. K. S., Youell, S. J., Dewhurst, R. J., Lee, M. R. F., \& Scollan, N. D. (2002). Effect of ensiling on the fatty acid composition of the resultant silage. In: Durand JL, Emile JC, Huyghe C, Lemaire
G, editors. Multi-Function Grasslands, 7. Grassland Science in Europe, 100-101.

Weinberg, Z.G., Ashbell, G., Bolson, K.K., Pahlow, G., Hen, Y., \& Azrieli, A. (1995). The effect of a propionic acid bacterial inoculant applied at ensiling, with or without lactic acid bacteria, on the aerobic stability of pearl millet and maize silages. J Appl Bacteriol., 78(4), 430-436. doi: 10.1111/j.13652672.1995.tb03430.x.

Weissbach, F. (1996). New developments in crop conservation. Proceedings of the 11th International Silage Conference; Aberystwyth, IGER, 11-25.

Zahiroddini, H., Baah, J., \& McAllister, T. A. (2006). Effects of microbial inoculants on the fermentation, nutrient retention, and aerobic stability of barley silage. Asian-Aust J Anim Sci., 19(10), 1429-1436. doi: 10.5713/ajas.2006.1429.

Zahiroddini, H., Baah, J., Absalom, W., \& McAllister, T. A. (2004). Effect of an inoculant and hydrolytic enzymes on fermentation and nutritive value of whole crop barley silage. Anim Feed Sci Technol., 117(3-4), 317-330. doi: 10.1016/j.anifeedsci.2004.08.013. 